\title{
Effect of climatic factors on the growth and leaf yield of betelvine (Piper betle $\mathbf{L}$.)
}

\section{Hrisita Mohanta* and Anupam Pariari}

Department of Spices and Plantation Crops, Faculty of Horticulture, Bidhan Chandra Krishi Viswavidyalaya, (Mohanpur 741252) West Bengal, INDIA

Dr. Anupam Pariari, B-1/481, Kalyani, Nadia -741235 (West Bengal) INDIA

*Corresponding author. E-mail: hrisita.mahanta@gmail.com

Received: October 13, 2015; Revised received: March 17, 2016; Accepted: June 5, 2016

Abstract: An experiment was conducted on eight cultivars of betelvine (Piper betle L.) with an objective to study the effect of various climatic factors on growth and leaf yield of the crop for consequtive two growing seasons. The experiment was designed in Completely Randomized Design with eight treatments (cultivars) and five replications. The data on growth and yield parameters were recorded in four different seasons of the year i.e., winter, summer, rainy and autumn season. Results showed that growth and leaf yield of betelvine was more in rainy season and less in winter season. Among the cultivars, vine length increment of cv. SimuraliSanchi was highest in rainy season $(144.70 \mathrm{~cm})$ followed by autumn season $(104.52 \mathrm{~cm})$, summer season $(98.40 \mathrm{~cm})$ and winter season $(48.56 \mathrm{~cm})$. Irrespective of all the seasons, cv. CARI-6 showed the maximum and Jabalpur showed the minimum internodal length. Among the cultivars SimuraliSanchi produced the maximum marketable leaves (23) per vine in rainy season. Temperature and relative humidity were positively correlated with variation in growth and yield parameters.

Keywords: Betelvine, Climate, Growth, Yield

\section{INTRODUCTION}

Betelvine is an important cash crop in India. It is one of the most important commercial crop, mainly grown by small and marginal farmers in the states of Assam, West Bengal, Bihar, Andhra Pradesh, Karnataka, Tamil Nadu, Maharashtra, Madhya Pradesh, Kerala, Uttar Pradesh and Orissa with an estimated area of 53,539 ha. Annual production is worth Rs. 9000 million and estimated that about 20 million people earn their livelihood directly or indirectly partly or fully from production, processing, handling, transportation and marketing of betel leaves in India (Suryanarayana et al., 2014).

Betelvine is cultivated in a 'boroj', with a specific microclimate. Various climatic factors like temperature, relative humidity and canopy temperature play an important role on growth and yield of betelvine (Walker, 1965). Water plays a key role in photosynthesis, stomatal opening, growth and expansion of leaf (Acharya et al., 2013). As leaves are consumed directly as masticatory, usage of biofertilizer was very essential, because the insoluble phosphate which was not directly available to plants usually comprises 9599\% of the total soil phosphorus (Anitha et al., 2015). Pariari and Imam (2012) evaluated 14 cultivars of betel vine in the gangetic alluvial plains of West Bengal and indicated that there was a wide variation among them for growth parameters. Sheet (2002) observed that cv. Chandrakona was superior with re- spect to most of the leaf characters compared to other cultivars.

Though there are some constraints of betelvine cultivation like lack of information, high labour cost, low producer price (Suranse and Bhople, 2004) but it is a perennial source of employment (Prasad and Prasad, 2003). Leaf is the economic part in betelvine. Keeping this point in mind, the present study was conducted to identify the most suitable season for the best growth of betel vine and the climatic factors that influences the growth and yield parameters of betelvine significantly and to identify the cultivars which produce highest number of leaves per vine in different seasons.

\section{MATERIALS AND METHODS}

The experiment was carried out throughout the year from December 2012 to November 2014 at Horticultural Research Station, Bidhan Chandra Krishi Viswavidyalaya, Mondouri, Nadia, WestBengal. The experiment was laid out in Completely Randomised Design with five replications. Eight cultivars like Simurali Jhal, Halisahar Sanchi, Jabalpur, Simurali Bhabna, Kalipatti, Simurali Sanchi, CARI-6 and CARI -2 were considered as treatments. During the experimental period several parameters like vine length increment, girth of vine, petiole length, internodal length, leaf number per vine were recorded. Vine length increment and total length of the vine was measured at 15 days and each three month interval. 
Growth during a specific period was calculated by deducting the previous length obtained up to beginning of the month from total length obtained up to last date of the specific period. Before lowering of vine, length of the vine was measured. Internodal length and petiole length was measured each month with measuring scale and mean data over the year was considered for analysis. Leaf yield was obtained by counting the number of leaves harvested throughout the year. The methodology is collaborated with the method applied by Pariari and Imam (2012) to evaluate vine length, intermodal length, petiole length and leaf yield of betelvine at gangetic alluvial plains of West Bengal.

On the other side, effect of various climatic factors like maximum and minimum temperature, relative humidity and canopy temperature inside the boroj were recorded through thermometer and hygrometer.The vine length increment, internodal length and petiole length of five plants each of 8 cultivars was recorded in $\mathrm{cm}$ at an interval of 15 days with the measuring scale during experiment, while girth of vine was measured with slide callipers. Total number of leaf per season were recorded at 15 days interval and then summed up to get total number of leaves produced by a vine in every season (Das, 2011).

The data obtained from each cultivar were analysed statistically by the analysis of variance method. The significance of different sources of variation was tested by error mean square by Fisher - Sendecors F test at probability levels of 0.05 . For computation of Critical Difference (C.D) at $5 \%$ level of significance, the statistical table formulated by Fisher and Yates (1979) was consulted.

\section{RESULTS AND DISCUSSION}

Vine length increment: In rainy season, vine length increment of all the cultivars recorded maximum over the year. Vine length increment of Simurali Sanchi was more in this season $(144.70 \mathrm{~cm})$ and less in winter season $(48.56 \mathrm{~cm})$. Similar findings on betelvine was recorded by Pariari and Imam 2012 at research station of $\mathrm{BCKV}$, where the average temperature was $9.48^{\circ} \mathrm{C}$ to $36.52^{\circ} \mathrm{C}$ and relative humidity ranged from $41.30 \%$ to $98.90 \%$. In winter season, vine length increment of betelvine was very less mainly due to low temperature $\left(10-28^{0} \mathrm{c}\right)$ prevailing in this period. Vine length increment of all the cultivars showed variation among themselves except CARI-6 $(127.45 \mathrm{~cm})$ and CARI-2 $(125.60 \mathrm{~cm})$ in rainy season (Table1.).

Vine girth: Vine girth of different cultivars of betelvine did not show any significant variation among themselves in different seasons except rainy season. In rainy season, girth of vine was maximum for all the cultivars in comparison to other seasons. Highest vine girth was observed in CARI-6, whereas, minimum was recorded in HalisaharSanchi (Table 1). In summer season, maximum and minimum vine girth was observed in CARI-6 $(1.38 \mathrm{~cm})$ and SimuraliBhabna $(1.21 \mathrm{~cm})$ respectively.
Internodal length: The variation in internodal length in all the cultivars might be due to inherent character of the cultivar and change in climatic pattern. Irrespective of all the seasons CARI- 6 showed maximum and Jabalpur showed minimum internodal length among all the cultivars (Table 1). In winter season due to low temperature $\left(10-28^{\circ} \mathrm{C}\right)$ internodal length was minimum, because vine length increment was low in this season. Das et al. (1995) reported the same result in betelvine, where temperature and relative humidity varied between $8.52^{\circ}-26.36^{\circ} \mathrm{c}$ and $94 \%$.Inwinterseason, SimuraliJhal $(4.54 \mathrm{~cm})$, SimuraliBhabna $(4.60 \mathrm{~cm})$ and Kalipatti $(4.25 \mathrm{~cm})$ did not show any statistical variation among themselves for internodal length.

Petiole length: In rainy season, Jabalpur $(10.48 \mathrm{~cm})$ and SimuraliSanchi $(6.42 \mathrm{~cm})$ produced the highest and the lowest petiole length respectively (Table 1). Rainy season was the most favourable season to produce the longest petiole for all betelvine cultivars than summer, autumn and winter seasons. Rahaman et al. (1997) evaluated 27 genotypes of betelvine at $30{ }^{\circ} \mathrm{C}$ temperature and $90 \%$ relative humidity for their yield attributes and reported that variation of petiole length varied between $5.9-17.50 \mathrm{~cm}$ in 27 genotypes of betelvine. There was no statistical variation of petiole length among HalisaharSanchi $(6.34 \mathrm{~cm})$, Kalipatti $(6.50 \mathrm{~cm})$ and SimuraliSanchi $(6.03 \mathrm{~cm})$ in autumn season.

Leaf number per vine: Generally leaf is the main commercial part of betelvine. Yield of betelvine is calculating by counting the number of leaves per vine. In winter season, as growth of vine was negligible, so production of leaf was also very less. In rainy season, more number of leaves were produced compare to winter, summer and autumn seasons. Among all the cultivars, SimuraliSanchi (23) produced more number of leaves and Jabalpur (10.33) produced less number of leaves (Table 1). Choudhury (2006) evaluated different betelvine cultivars through integrated nutrient management practices at horticultural research station, Mondouri, BCKV and stated that, among all the cultivars SimuraliSanchi produced the highest number of leaves per vine followed by SimuraliBhabna.

Effect of climatic factors on growth and yield of betelvine: In winter season, due to low temperature and low humidity slow growth of vine was seen. High humidity and optimum temperature prevailing in rainy season influenced the growth of betelvine to a maximum extent. This variation is mainly due to change in climatic factors like temperature, relative humidity and canopy temperature (inside the boroj) etc. Vine length of Jabalpur was not influenced by canopy temperature (Table 2). Minimum temperature and relative humidity were significantly correlated at $5 \%$ and $1 \%$ level with development of vine girth (Table 2). Vine girth of Jabalpur was influenced by minimum temperature along with relative humidity within the canopy and in Kalipatti. Das (2011) reported that vine girth of Kalipatti was effectively influenced by relative humid- 
ity $(94 \%)$ and minimum temperature $\left(8.52^{\circ}-26.36^{\circ} \mathrm{C}\right)$ of the boroj. It was found that minimum temperature and relative humidity inside the boroj had close association with internodal length for all the cultivars of betelvine except CARI 2 (Table 2). Maximum temperature and canopy temperature were found more effective in HalisaharSanchi, Jabalpur, SimuraliBhabna and Kalipatti for development of petiole (Table 2). Hovenden et al. (2012) did a study regarding impact of relative humidity on Nothofagus cunninghamii and reported that growth parameters were strongly influenced by relative humidity. Wilson and Cooper (1969) evaluated that variation of temperature results, changes in mesophyll cell size and/or stomatal anatomy, may influence the subsequent rate of photosynthesis, which related to leaf growth of Lolium genotypes. In rainy season, plant produced maximum number of leaves because high humidity and moderate temperature was suitable for its cultivation. Minimum temperature and relative humidity played significant role to produce more number of leaves per vine. But maximum temperature did not have any effect on production of leaves in cv. Simurali Jhal (Table 2). By increasing humidity inside the growing structure betelvine can be grown luxuriantly with a production of broad, light green yellow and feathery leaves due to effect of microclimate (Balasubramanium, 1987).

\section{Concluson}

As leaf is the economic part of betelvine and leaf production is the key factor for economic analysis of the crop. Yield of the crop varies with the season. The present study concluded that rainy season is the most favourable season for betel vine's growth and development. Temperature and relative humidity were found to be the most important factors for variation in growth and yield parameters. Among the cultivars Simurali Sanchi produced the maximum marketable leaves per vine per year due to profuse vine growth compare to other cultivars.

\section{REFERENCES}

Acharya, S.K., Shukla, Y.R. and Khatik, P.C. (2013). Impact on water regime on growth and yield of lettuce (Lactucasativa L.). The Bioscan., 8 (1): 201-206.

Anitha, M., Swami, D.V. and Suneetha, D.R.S. (2015). Seed yield and quality of fenugreek (Trigonella foenumgraecum) cv. Lam Methi -2 as influenced by integrated nutrient management. The Bioscan. 10 (1): 105-106.

Balasubramanium, A. (1987). Microclimate and its utilization in Indian farming. ILEIA Newsletter. 3.3 October 1987.2.

Choudhury, S.M. (2006). Evaluation of betelvine cultivars through integrated nutrient practices and post harvest technology management. M. Sc. Thesis, Bidhan Chandra Krishi Viswavidyalaya, West Bengal. India.

Das, J.N., Das, S.C., Mohanty, C.R. and Nayak, B.B. (1995). Relative performance of some bangla cultivars of betelvine (Piper betle L.) at Bhubaneswar. Orissa Journal of Horticulture, 23 (1-2): 104-107.

Das, L. (2011). Studies on growth and productivity of betelvine (Piper betle L.) as influenced by climate. M.Sc Thesis, Bidhan Chandra Krishi Viswavidyalaya, West Bengal. India.

Fisher, R.A. and Yates, F. (1979). In. Statistical tables for biological Agriculture and medicinal research $\left(6^{\text {th }}\right.$ edition), Longman group. London.

Hovenden, M.J., Jacqueline, K., Vander, S. and Yui, O. (2012). Relative humidity has dramatic impacts on leaf morphology but little effect on stomatal index or density in Nothofaguscunning hami(Nothofagaceae). Austrelian Journal of Botany, 60 (8).

Pariari, A. and Imam, M.N. (2012). Evaluation of betelvine (Piper betle L.) cultivars in the gangetic alluvial plains of West Bengal. Journal of Spices and Aromatic Crops. 21: 1-8.

Prasad. B and Prasad. S. (2003). Pattern of employment in betelvine cultivation. Journal of Applied Biology, 13 (1/2): 125-129.

Rahaman, M., Dasi, N.D. and Jana, S.C. (1997). Phenotypic establish for yield and yield attributes of betelvine (Piper betle L.). Econ. Bot Information Service, Nat. Bot. Res. Inst. Lucknow, pp. 105-109.

Sheet, S.K. (2002).Evalution of betelvine (Piper betle L.) germplasm for quality.M.Sc. Thesis submitted to Bidhan Chandra Krishi Viswavidyalaya, West Bengal, India. pp-27-28.

Suranse, P.K and Bhople, R.S. (2004).Constraints in adoption of improved betelvine cultivation practices. Journal -of-Soils-and-Crops, 14 (2): 312-316.

Suryanarayana, M.A., Vasantha, K.T., Hima, B.K. and Lokesha, A.N. (2014). Status of Betelvine cultivation in Karnataka. Conference paper. Section of Medicinal Crops, Indian Institute of Horticultural Research, Bangalore.

Walker, J.C. (1965). Use of environmental factors in screening for disease resistance. Ann. Rev. Phytopathol., 3: $197-208$.

Wilson, D. and Cooper, J.P. (1969). Effect of temperature during growth on leaf anatomy and subsequent light saturated photosynthesis among contrasting Lolium genotypes. New Phytol., 68: 1115-1123. 